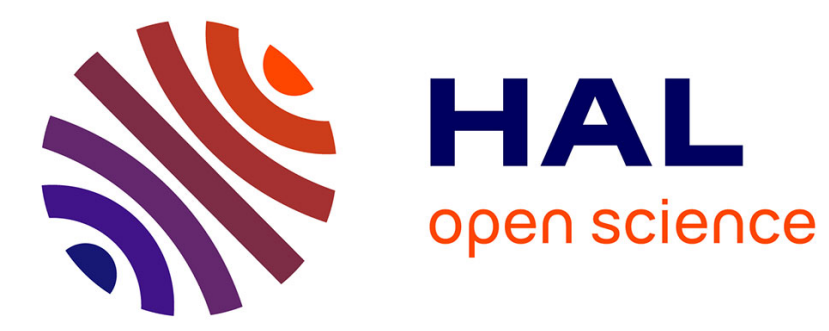

\title{
Synthesis of conjugated multi-ynamides by copper-catalyzed reactions
}

\author{
Marie Betou, Antoine Sallustrau, Loic Toupet, Yann Trolez
}

\section{To cite this version:}

Marie Betou, Antoine Sallustrau, Loic Toupet, Yann Trolez. Synthesis of conjugated multiynamides by copper-catalyzed reactions. Tetrahedron Letters, 2015, 56 (31), pp.4627-4630. 10.1016/j.tetlet.2015.06.027 . hal-01163651

HAL Id: hal-01163651 https://hal-univ-rennes1.archives-ouvertes.fr/hal-01163651

Submitted on 19 Nov 2015

HAL is a multi-disciplinary open access archive for the deposit and dissemination of scientific research documents, whether they are published or not. The documents may come from teaching and research institutions in France or abroad, or from public or private research centers.
L'archive ouverte pluridisciplinaire HAL, est destinée au dépôt et à la diffusion de documents scientifiques de niveau recherche, publiés ou non, émanant des établissements d'enseignement et de recherche français ou étrangers, des laboratoires publics ou privés. 


\title{
Synthesis of conjugated multi-ynamides by copper-catalyzed reactions
}

\author{
Marie Betou, ${ }^{a}$ Antoine Sallustrau, ${ }^{a}$ Loïc Toupet, ${ }^{b}$ Yann Trolez ${ }^{\mathrm{a}, *}$ \\ ${ }^{[a]}$ Ecole Nationale Supérieure de Chimie de Rennes, UMR 6226, CNRS, 11 allée de Beaulieu, \\ CS 50837, 35708 Rennes Cedex 7, France. Fax: 332232381 08; Tel: 332232380 69; E-mail: \\ yann.trolez@ensc-rennes.fr \\ ${ }^{[b]}$ Institut de Physique de Rennes, CNRS, UMR 6251, Université de Rennes 1, Rennes, France
}

\section{Abstract}

The synthesis of multi-ynamides according to the copper-catalyzed Evano's and Hsung's methods is described. In these new compounds, the ynamide functions are conjugated to each other with a phenyl, a biphenyl, a thienyl or a triphenylamine spacer.

\section{Keywords}

Ynamide; copper-catalysis; biphenyl; thiophene; triphenylamine

\section{Introduction}

Ynamides have found an increasing interest over the last decade. ${ }^{1}$ These benchstable homologues of ynamines have been the subject of numerous publications these last years. Their particular properties have been deeply studied, both from chemical and physical points of view. ${ }^{2}$ This late interest, compared to ynamines, ${ }^{3}$ can be explained by quite recent breakthroughs concerning their methods of synthesis since $2003 .{ }^{4}$ Indeed, three major methodologies using copper-catalysts have been developed by different teams. The first one was described by Hsung group in 2003 and uses 1-bromoacetylenes as substrates. ${ }^{5}$ The second one was proposed by Stahl group in 2008 and directly uses terminal acetylenes as substrates in oxidative conditions, ${ }^{6}$ avoiding thus the necessity to activate the $\mathrm{CC}$ triple bond by substituting it with a bromine. ${ }^{7}$ The third and last one was described by Evano group in 2009 and uses gem-dibromovinyl compounds as substrates, allowing the possibility to create the CC triple bond during the ynamide formation (Figure 1 ). ${ }^{8}$ The description would not be complete without mentioning the precursor work of Danheiser group who first developed a methodology using copper, in significantly more basic conditions though. ${ }^{9}$ 



Figure 1. The three major methodologies developed by Hsung, Stahl and Evano.

Whereas an important number of "simple" ynamides (in the sense of compounds bearing just one ynamide function) has now been reported, ${ }^{10}$ the description of "multiple" ynamides remains quite scarce. ${ }^{11}$ However, their potential in organic synthesis is very interesting. In particular, it could be interesting to evaluate the reactivity of the ynamide functions when they are conjugated. Indeed, a reaction on one ynamide moiety could dramatically influence the reactivity of the second conjugated ynamide moiety. This point has almost never been investigated so far since there are only three reports of the synthesis of conjugated bis-ynamides, to the best of our knowledge. ${ }^{11^{b, c, g}}$ We describe here the synthesis of some tosylated multiple ynamides conjugated to one another using coppercatalyzed methods.

\section{Results and discussion}

We first started with the synthesis of the para-phenyl bis-ynamide 1. For that purpose, the Hsung method was chosen. Dibrominated compound $2^{12}$ was reacted with $\mathrm{N}$ methyltosylamide in the presence of potassium carbonate and a catalytic amount of copper sulfate and 1,10-phenanthroline at $75{ }^{\circ} \mathrm{C}$ in toluene for 40 hours. The corresponding bisynamide 1 was obtained in 55\% yield (Scheme 1). During the course of our work, Evano and coworkers also synthesized a similar bis-ynamide bearing two additional methyl groups in para-positions opposite to each other. ${ }^{11 g}$ 
The same strategy was used to synthesize the corresponding biphenyl analogue $\mathbf{3}$ from compound 4 . Increasing the temperature to $90{ }^{\circ} \mathrm{C}$ allowed us to decrease the reaction time (16 hours). Compound 3 was thus obtained in $75 \%$ yield.


Scheme 1. Synthesis of the bis-ynamides 1 and $\mathbf{3}$.

X-ray quality crystals of bis-ynamides $\mathbf{1}$ and $\mathbf{3}$ were obtained by evaporation of a dichloromethane solution for 1 and slow diffusion of cyclohexane in a dichloromethane solution for 3. It allowed us to obtain crystallographic structures of these two ynamides. For both of them, the length of the CC-triple bonds is $1.19 \AA$ and the one of the $\mathrm{C}_{\text {triple }}-\mathrm{N}$ is $1.36 \AA$ whereas the one of the $\mathrm{C}_{\mathrm{Me}}-\mathrm{N}$ is $1.47 \AA$. This significant difference in the length of the two types of $\mathrm{C}-\mathrm{N}$ is a general property of ynamides and can be explained by the delocalization of the electron doublet towards the CC triple bond. The nitrogen atoms are almost planar with a torsion angle with the surrounding atoms about $16^{\circ}$ for $\mathbf{1}$ and around $20^{\circ}$ for 3 . One can notice that the two adjacent phenyl rings of compound $\mathbf{3}$ are exactly in the same plane.
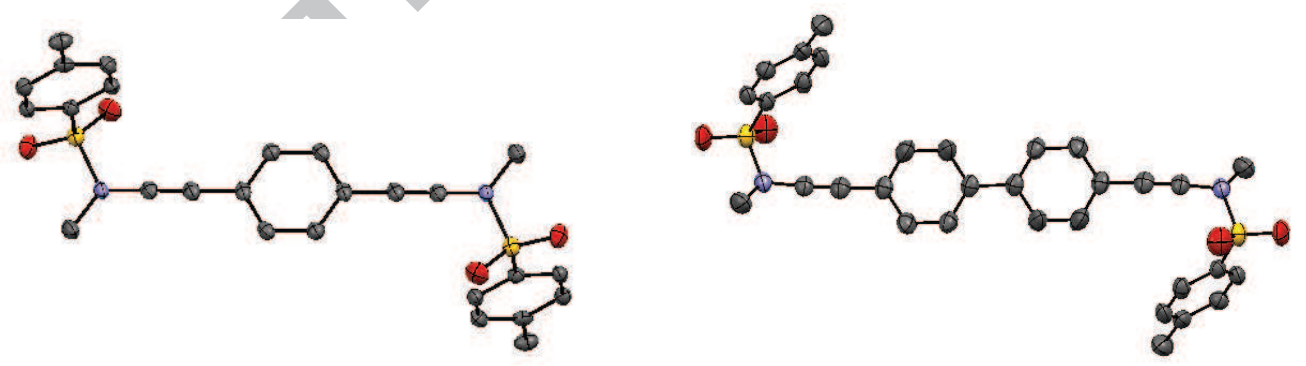

Figure 2. X-ray structures of bis-ynamides $\mathbf{1}$ and $\mathbf{3}$; protons have been omitted for clarity.

Given that Hsung's method seemed to be very well adapted to the synthesis of multiynamides conjugated with a phenyl ring, we investigated the possibility to go a step further by positioning three ynamide functions on the same phenyl. For this purpose, we first synthesized the 1,3,5-tris(bromoethynyl)phenyl moiety $\mathbf{5}$ using standard conditions. ${ }^{13}$ Then, it was reacted with four equiv. of $\mathrm{N}$-methyltosylamide in the presence of potassium 
carbonate, copper sulfate and 1,10-phenanthroline at $90{ }^{\circ} \mathrm{C}$ in toluene for 15 hours. After treatment, the target tris-ynamide 6 was obtained in a satisfying yield (41\%). To the best of our knowledge, this is the first report of a molecule containing three ynamide functions (scheme 2).

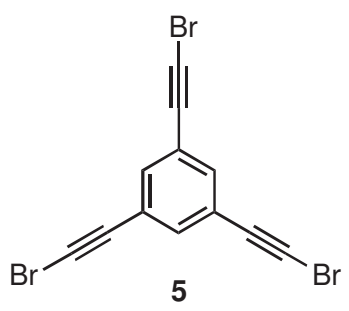

5

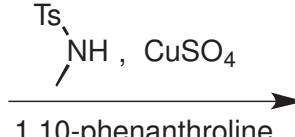

$\mathrm{K}_{2} \mathrm{CO}_{3}$

Toluene

$41 \%$

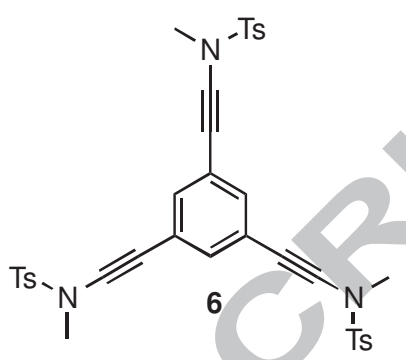

Scheme 2. Synthesis of the tris-ynamide 6.

Given the successful synthesis of the afore-mentioned ynamides 1,3 and 6, we tried to use Hsung's method to obtain the thiophene-conjugated bis-ynamide 7. Therefore, we synthesized the corresponding bis-bromoacetylenic thiophene 8 and reacted it in the conditions previously described. However, the target compound was not obtained this time. According to TLC analyses, the major part of the $\mathrm{N}$-benzyltosylamide, which was introduced in a stoichiometric amount, did not react. This lack of reactivity of the partners can be explained by the supposed instability of compound 8 at $90{ }^{\circ} \mathrm{C}$. In order to overcome this problem, we tested a double Sonogashira coupling between 2,5-dibromothiophene with ynamide $9^{14}$ following the conditions described by Hsung and co-workers for such couplings. ${ }^{15}$ Once again, this attempt did not lead to the expected ynamide. We thus decided to try Evano's method to access the target compound. Consequently, we synthesized the 2,5-bis(gem-dibromovinyl)thiophene $10^{16}$ reacted it with $N$-benzyltosylamide, copper iodide, $N, N^{\prime}$-dimethylethylenediamine and cesium carbonate to afford the target bis-ynamide $\mathbf{7}$ in $29 \%$ yield (scheme 3 ). 


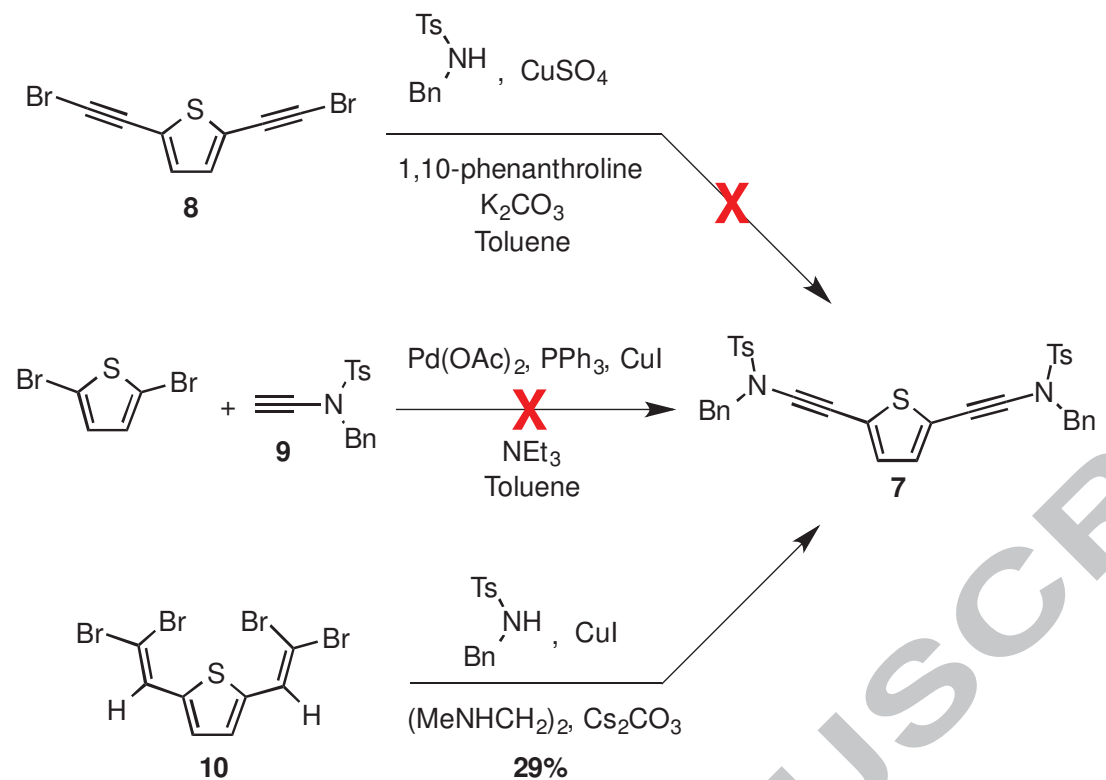

Scheme 3. Successful and unsuccessful strategies leading to bis-ynamide 7.

We also wanted to functionalize a triphenylamine core with two ynamide functions. Considering the unequal fates of the strategies employed for the synthesis of compound $\mathbf{7}$, we decided to use Evano's method to obtain the target molecule. Therefore, we turned the triphenylamine 12 functionalized with two aldehyde groups ${ }^{17}$ into a bis-(gemdibromovinyl)triphenylamine 13 using standard conditions. Then, compound 13 was submitted to Evano's conditions with $\mathrm{N}$-benzyltosylamide. Contrary to what was expected, the expected bis-ynamide could not be isolated pure since all the $\mathrm{N}$-benzyltosylamide did not react and could not be separated from the bis-ynamide by column chromatography or other usual purification techniques. Consequently, the mono-ynamide $\mathbf{1 4}$ was first isolated in $54 \%$ (by using 0.9 equiv of $\mathrm{N}$-benzyltosylamide) and then submitted to another reaction with $\mathrm{N}$-benzyltosylamide in Evano's conditions to afford the target triphenylamine 15 functionalized with two ynamide functions in $40 \%$ yield (scheme 4 ). 
<smiles>C=C(C)c1ccc(N(C2=CC=CCC2)C2C=CC(CO)=CC2)cc1</smiles>

12
$\mathrm{LBr} \mathrm{Br}_{4} \cdot \mathrm{PF}^{3}$

$$
61 \%
$$<smiles>FC(=C(Br)C(Br)Br)c1ccc(N(c2ccccc2)C2C=CC(=CCCl)CC2)cc1</smiles>

15

$T_{\mathbf{3}}$



$51 \%$

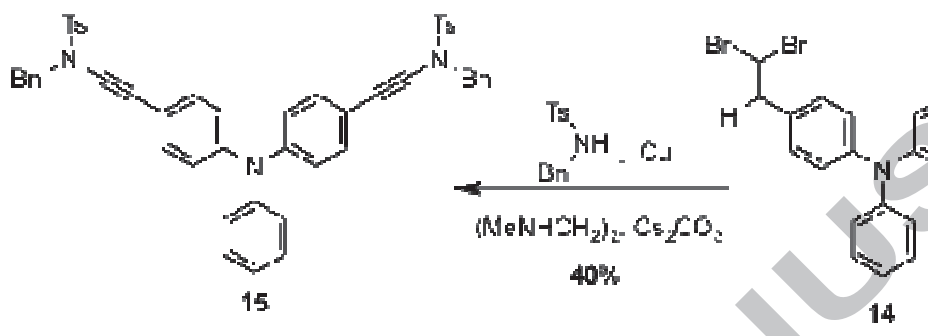

Scheme 4. Synthesis of triphenylamine 15.

\section{Conclusion}

To conclude, we described the synthesis of five original multiple ynamides, using the methods described by the groups of Hsung and Evano. This report includes the synthesis of a tris-ynamide, which is the first one reported to the best of our knowledge. Hsung's and Evano's methods appeared as complementary methods to access the target compounds. The possibility to use different kinds of precursors (1-bromoalkynes versus gemdibromovinyls) is a real advantage for the organic chemists aiming to access particular ynamides. The evaluation of the reactivity of these multiple ynamides is currently under progress in our laboratory and will be reported in due course.

\section{Supplementary data}

Synthetic procedures of compounds $1,3,6,7,14$ and 15 can be found in supporting information. CCDC-1002889 and CCDC-1401629 contain the supplementary crystallographic data for this paper. These data can be obtained free of charge from The Cambridge Crystallographic Data Centre via www.ccdc.cam.ac.uk/data_request/cif.

\section{Acknowledgments}


M. B. and A. S. thank the Région Bretagne for a post-doctoral grant.

\section{References}

${ }^{1}$ a) Evano, G.; Coste, A.; Jouvin, K. Angew. Chem. Int. Ed. 2010, 49, 2840-2859; b) DeKorver, K. A.; Li, H.; Lohse, A. G.; Hayashi, R.; Lu, Z.; Zhang, Y.; Hsung, R. P. Chem. Rev. 2010, 110 , 5064-5106.

${ }^{2}$ For selected recent examples: a) Kohnen, A. L.; Mak, X. Y.; Lam, T. Y.; Dunetz, J. R.; Danheiser, R. L. Tetrahedron 2006, 62, 3815-3822; b) Dooleweerdt, K.; Ruhland, T.; Skrydstrup, T. Org. Lett. 2009, 11, 221-224; c) Witulski, B.; Shweikert, T.; Schollmeyer, D.; Nemkovich, N. A. Chem. Commun. 2010, 46, 2953-2955; d) Li, H.; Hsung, R. P.; DeKorver, K. A.; Wei, Y. Org. Lett. 2010, 12, 3780-3783; e) Gomes, F.; Fadel, A.; Rabasso, N. J. Org. Chem. 2012, 77, 5439-5444; f) Clavier, H.; Lepronier, A.; Bengobesse-Mintsa, N.; Gatineau, D.; Pelissier, H.; Giordano, L.; Tenaglia, A.; Buono, G. Adv. Synth. Cat. 2013, 355, 403-408; g) Hentz, A.; Retailleau, P.; Gandon, V.; Cariou, K.; Dodd, R. H. Angew. Chem. Int. Ed. 2014, 53, 8333-8337; h) Betou, M.; Kerisit, N.; Meledje, E.; Leroux, Y. R.; Katan, C.; Halet, J.-F.; Guillemin, J.-C.; Trolez, Y. Chem. Eur. J. 2014, 20, 9553-9557.

${ }^{3}$ Collard-Motte, J.; Janousek, Z. Top. Curr. Chem. 1986, 130, 89-131.

${ }^{4}$ a) Witulski, B.; Stengel, T. Angew. Chem. Int. Ed. 1998, 37, 489-492; b) Yao, B.; Liang, Z.; Niu, T.; Zhang, Y. J. Org. Chem. 2009, 74, 4630-4633; C) Jouvin, K.; Couty, F.; Evano, G. Org. Lett. 2010, 12, 3272-3275; d) Jia, W.; Jiao, N. Org. Lett. 2010, 12, 2000-2003; e) Aubineau, T.; Cossy, J. Chem. Commun. 2013, 49, 3303-3305; f) Mansfield, S. J.; Campbell, C. D.; Jones, M. W.; Anderson, E. A. Chem. Commun. 2015, 51, 3316-3319.

${ }^{5}$ Frederick, M. O.; Mulder, J. A.; Tracey, M. R.; Hsung, R. P.; Huang, J.; Kurtz, K. C. M.; Shen, L.; Douglas, C. J. J. Am. Chem. Soc. 2003, 125, 2368-2369.

${ }^{6}$ Hamada, T.; Ye, X.; Stahl, S. S. J. Am. Chem. Soc. 2008, 130, 833-835.

${ }^{7}$ The very first example of such a coupling was described by Domiano in 1985: Domiano, P. Tetrahedron Lett. 1985, 26, 4141-4144.

${ }^{8}$ Coste, A.; Karthikeyan, G.; Couty, F.; Evano, G.; Angew. Chem. Int. Ed. 2009, 48, 4381-4385.

${ }^{9}$ Dunetz, J. R.; Danheiser, R. L. Org. Lett. 2003, 5, 4011-4014.

${ }^{10}$ a) Witulski, B.; Stengel, T. Angew. Chem. Int. Ed. 1999, 38, 2426-2430; b) Brückner, D. Synlett 2000, 10, 1402-1404; c) Wei, L.-L.; Mulder, J. A.; Xiong, H.; Zificsak, C. A.; Douglas, C. J.; Hsung, R. P. Tetrahedron 2001, 57, 459-466; d) Dooleweerdt, K.; Birkedal, H.; Ruhland, T.; Skrydstrup, T. J. Org. Chem. 2008, 73, 9447-9450; e) Jouvin, K.; Heimburger, J.; Evano, G. Chem. Sci. 2012, 3, 756-760.

${ }^{11}$ Here is a list of reports describing the synthesis of multiple ynamides: a) Witulski, B.; Alayrac, C. Angew. Chem. Int. Ed. 2002, 41, 3281-3284; b) Martinez-Esperon, M. F.; Rodriguez, D.; Castedo, L.; Saa, C. Tetrahedron 2006, 62, 3843-3855; c) Zhang, X.; Li, H.; You, L.; Tang, Y.; Hsung, R. P. Adv. Synth. Catal. 2006, 348, 2437-2442; d) Buissonneaud, D.; Cintrat, J.-C. Tetrahedron Lett. 2006, 47, 3139-3143; e) Rodríguez, D.; Martínez-Esperón, M. F.; Castedo, L.; Saá, C. Synlett 2007, 12, 1963-1965;;f) Jouvin, K.; Coste, A.; Bayle, A.; Legrand, F.; Karthikeyan, G.; Tadiparthi, K.; Evano, G. Organometallics 2012, 31, 7933-7947; g) Theunissen, C.; Métayer, B.; Henry, N.; Compain, G.; Marrot, J.; Martin-Mingot, A.; Thibaudeau, S.; Evano, G. J. Am. Chem. Soc. 2014, 136, 12528-12531; h) Campbell, C. D.; Greenaway, R. L.; Holton, O. T.; Chapman, H. A.; Anderson, E. A. Chem. Commun. 2014, 50, 5187-5189.

12 Li, M.; Li, Y.; Zhao, B.; Liang, F.; Jin, L.-Y. RSC Adv. 2014, 4, 30046-30049. 
${ }^{13}$ Zhu, S.; Xiao, Y.; Guo, Z.; Jiang, H. Org. Lett. 2013, 15, 898-901.

${ }^{14}$ Brückner, D. Tetrahedron 2006, 62, 3809-3814.

${ }^{15}$ Tracey, M. R.; Zhang, Y.; Frederick, M. O.; Mulder, J. A.; Hsung, R. P. Org. Lett. 2004, 6, 2009-2012.

${ }^{16}$ Hwang, G. T.; Son, H. S.; Ku, J. K.; Kim, B. H. J. Am. Chem. Soc. 2003, 125, 11241-11248.

${ }^{17}$ Liu, B.; Zhang, Q.; Ding, H.; Hu, G.; Du, Y.; Wang, C.; Wu, J.; Li, S.; Zhou, H.; Yang, J.; Tian, Y. Dyes and Pigments 2012, 95, 149-160. 


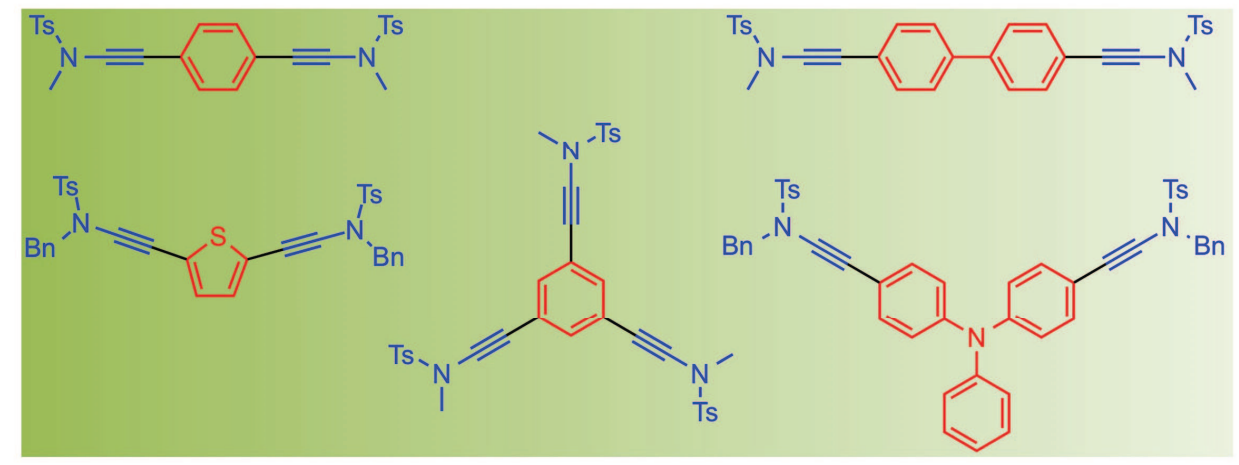

\section{Graphical abstract}

